\title{
THE EFFECT OF CORPORATE SOCIAL RESPONSIBILITY ON WORD OF MOUTH WITH TRUST AND CORPORATE REPUTATION AS INTERVENING VARIABLE
}

\author{
Alif Supriyatno, Siti Dyah Handayani \\ Faculty of Economics and Business, Management Department, Universitas Muhammadiyah \\ Yogyakarta,Indonesia \\ alif.supriyatno1@gmail.com
}

\begin{abstract}
This study aims to determine the effect of corporate social responsibility on word of mouth with trust and corporate reputation as mediating variable, study on Hero Supermarket customer in Yogyakarta. The sampling method used in this study is purposive sampling. The number of samples in this study is 130 customers of Hero Supermarket in the last 6 months. Data were collected using questionnaire, analyzed using structural equation modeling with Amos vers. 22.0 software. The result of this study proves that corporate social responsibility has positive and significant effect on trust, corporate social responsibility has positive and significant effect on corporate reputation, corporate social responsibility has no significant effect on word of mouth, trust has no significant effect on word of mouth, corporate reputation has positive and significant effect on word of mouth, trust could not mediate the effect of corporate social responsibility on word of mouth and corporate social responsibility indirectly has higher effect on word of mouth through corporate reputation.
\end{abstract}

Keywords: Corporate Social Responsibility, Trust, Corporate Reputation and Word of Mouth.

\section{INTRODUCTION}

The marketing concept always changes in accordance with the dynamics of times development. The latest concept ehich still develops is Holistic marketing. The holistic marketing concept is an approach which integrates the complexity of marketing activities that consists of four components: integrated marketing, relationship marketing, internal marketing, and performance marketing [1].

This research focused on two components of holistic marketing concept that namely relationship marketing and performance marketing. Relationship marketing is a concept that aims to build a long-term relationship with customer, distributor and all of the key constituents to maintain the business [1]. While performance marketing is a marketing concept that cannot be separated from the legal, ethical, social and environmental issues [1]. 
Jurnal Manajemen Bisnis, Vol 9. No 2, September 2018, E-ISSN:2622-6308 P-ISSN:2086-8200

Website: http://journal.umy.ac.id/index.php/mb

DOI:10.18196/mb.9260

Performance marketing also refers to social marketing that requires the marketer to include the consideration of ethics into marketing practices [1].

There are research gaps that try to be reanalyzed with this research, the first research gap from [2] stated that corporate social responsibility has positive and significant effects on corporate reputation, meanwhile [3] stated that corporate social responsibility does not have effect on corporate reputation. The second research gap comes from [4] which states that corporate social responsibility directly effects word of mouth, different with [5] that stated the negation of it.

\section{LITERATURE REVIEW}

\section{Corporate Sosial Responsibity}

Corporate social responsibility has become a critical issue for stakeholders, especially in the business field. Corporate social responsibility is a form of company attention to create prosperity and goodness for the (external stakeholders). According to [6] corporate social responsibility can be interpreted as a commitment to improve the well-being of the community through the optional business practices. Corporate social responsibility activities can assist companies in establishing relationships with customers and build loyalty and it has proved to have a substantial positive effect on profit [7].

\section{Trust}

Trust is a very important element in the business and the lost of trust is the end of a business [8]. Trust is a statement that involves a positive expectation with in something risk, in this case trust is a belief that company will able to achieve the expectation of consumers [8].

\section{Corporate Reputation}

Corporate reputation is a psychological model that has effects an the quality perception of products or services provided by the company \& A good reputation is a valuable asset for the company [8]. The increase of reputation become the attraction of new customers and also creates a competitive advantage for the company [10]. Corporate reputation will provide the strategic impact for the company, so that reputation management is one of excellence competitive advantages in the business field [11]. 
Jurnal Manajemen Bisnis, Vol 9. No 2, September 2018, E-ISSN:2622-6308 P-ISSN:2086-8200

Website: http://journal.umy.ac.id/index.php/mb

DOI:10.18196/mb.9263

\section{Word Of Mouth}

Customer's word of mouth is a process of giving recommendation both individually and in group about a product or service that aims to provide personal information [7]. Personal communication in the form of word of mouth can be an effective method of promotion because it is generally delivered from consumers, by the consumers and for the consumers, so the satisfied customers can be an advertising media for the company [7]. In addition, word of mouth does not cost much because through satisfied customers, references about the products that are produced by the company will be more easily spread to other customers [7].

\section{HYPOTHESIS AND RESEARCH MODEL}

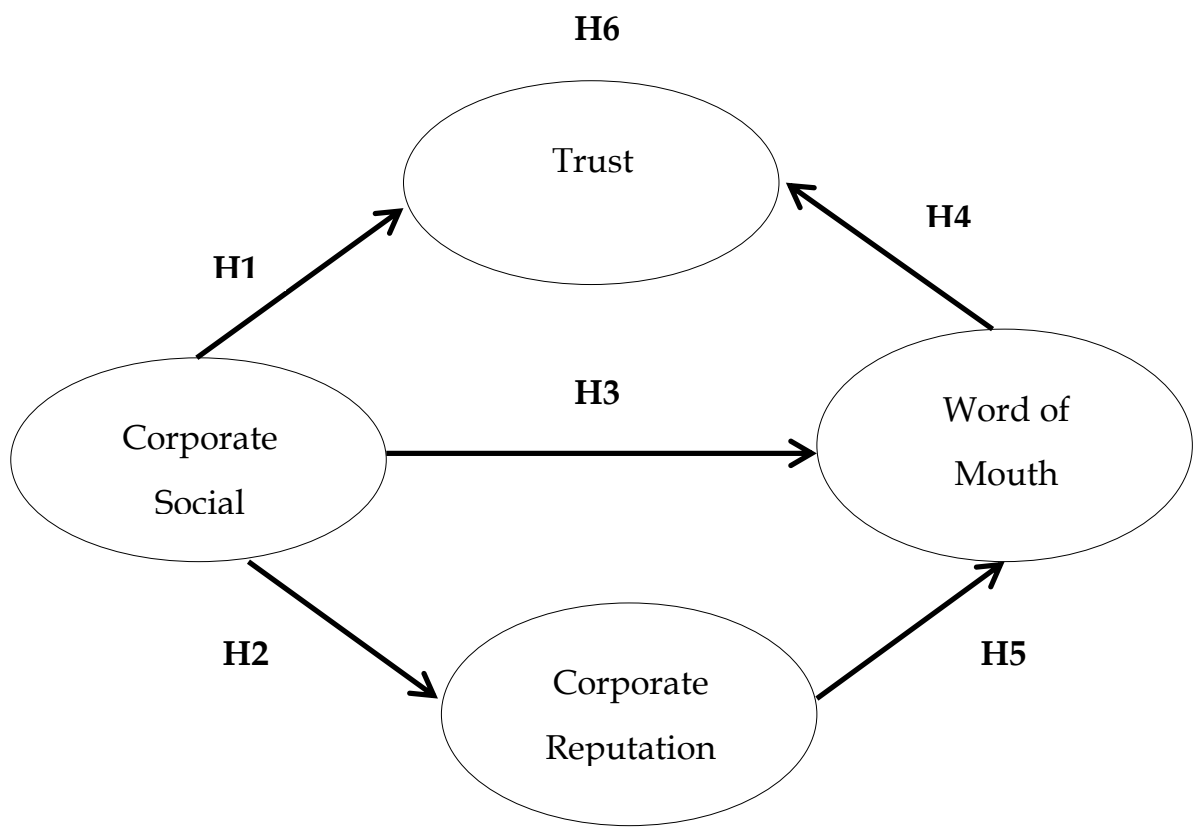

H7

Figure 1: Research Model

H1 : CSR has positive and significant effect on trust, [4] [5] [12]. 
Jurnal Manajemen Bisnis, Vol 9. No 2, September 2018, E-ISSN:2622-6308 P-ISSN:2086-8200

Website: http://journal.umy.ac.id/index.php/mb

DOI:10.18196/mb.9260

H2 : CSR has positive and significant effect on corporate reputation, [2] [10] [13] [14] [15] [16] [17] [18] [19].

H3 : CSR has positive and significant effect on Word of Mouth, [2] [5]

H4 : Trust has positive and significant effect on Word of Mouth, [5] [2]

H5 : Corporate reputation has positive and significant effect on Word of Mouth, [2]

H6 : Trust could mediate the effect of CSR on Word of Mouth, [5]

H7 : Corporate could mediate the effect of CSR on Word of Mouth, [2]

\section{METHOD}

The population of this research is consumers of Hero Supermarket-Yogyakarta, with the sample chosen by purposive technique sampling that correspondents should be above 17 years old, and have purchased in Hero Supermarket at least twice last month. In order to investigate the research objectives, primary data have been collected and analyzed. The data was collected through online questionnaire that was distributed using Google form. All variables were measured using five-point Likert scale from (1) Strongly Disagree, (2) Disagree, (3) Undecided, (4) Agree, (5) Strongly Agree. This research has a total of four constructs: CSR, trust, corporate reputation and Word of Mouth.

The validation test used Pearson's correlation and reliability test used Cronbach's Alpha. This Study used Structural Equation Modeling (SEM) to analyze hypothesis because SEM could give more goodness of fit indices for the full structural model, giving more superior empirical results [21].

\section{RESULTS AND DISCUSSION}

\section{Research Object}

The object of this research is the Hero Supermarket-Yogyakarta. Hero supermarket was chosen because, according to [22] consumers often continue the impression about restaurants, stores, or a new movie to friends, and Hero Supermarket actively promotes its corporate social responsibility programs in the official web page of Hero Supermarket and other media. Hero supermarkets also won as the Best Country for the CSR Excellence Award and CSR Leadership Award in the $9^{\text {th }}$ Annual Global CSR Summit and Conference in Langkawi-Malaysia on March 29, 2017. 
Jurnal Manajemen Bisnis, Vol 9. No 2, September 2018, E-ISSN:2622-6308 P-ISSN:2086-8200

Website: http://journal.umy.ac.id/index.php/mb

DOI:10.18196/mb.9263

Corporate social responsibility programs of PT Hero Supermarket Tbk. have been done in variety of sector such as education (MOGI Hero, Hero Teaching and Hero Books of Happiness), in the public health (Support \& Supplementary Feeding, Zumba Carnival and

Hero Healthy Project), economic empowerment (direct farmer and business mentoring program) and environmental sector (Hero Greenspiring Movement, Care to Share, reduction of plastic bags, Green Community, Biogas Program, Store Green Action: Greening School, and Store Green Action).

\section{Characteristic Of The Sample}

Table 1.below shows the characteristics of respondents in respect of age, gender, level of education, and buying frequency.

Table 1. Demographic profile of respondents $(n=130)$

\begin{tabular}{llc}
\hline & & Percentage (\%) \\
\hline Age & $17-25$ & 40,8 \\
& $26-35$ & 32,3 \\
& $36-50$ & 26,9 \\
Gender & Male & 46,2 \\
& Female & 53,8 \\
Job & Student & 36,1 \\
& Entrepreneur & 20 \\
& Civil Employee & 16,2 \\
Buying frequency & Other & 27,7 \\
& $2 x$ & 38,5 \\
& $>3 x$ & 25,4 \\
& & 36,2 \\
\hline
\end{tabular}

\section{Validity Test and Reliability Test}

The validity test shows all the results of pearson's correlation $<0,05$ means that all constructs are valid [23].The reliability test shows all the results cronbach's alpha $\geq 0,6$ with CSR 0,922; Trust 0,882; Corporate Reputation 0,879, and Word of Mouth 0,930, it mean that all constructs are reliable [23]. 
Jurnal Manajemen Bisnis, Vol 9. No 2, September 2018, E-ISSN:2622-6308 P-ISSN:2086-8200

Website: http://journal.umy.ac.id/index.php/mb

DOI:10.18196/mb.9260

\section{Hypotheses Testing By Structural Equation Modeling}

Testing of the hypotheses for this research is carried out by using SEM as displayed in Figure 2 below.

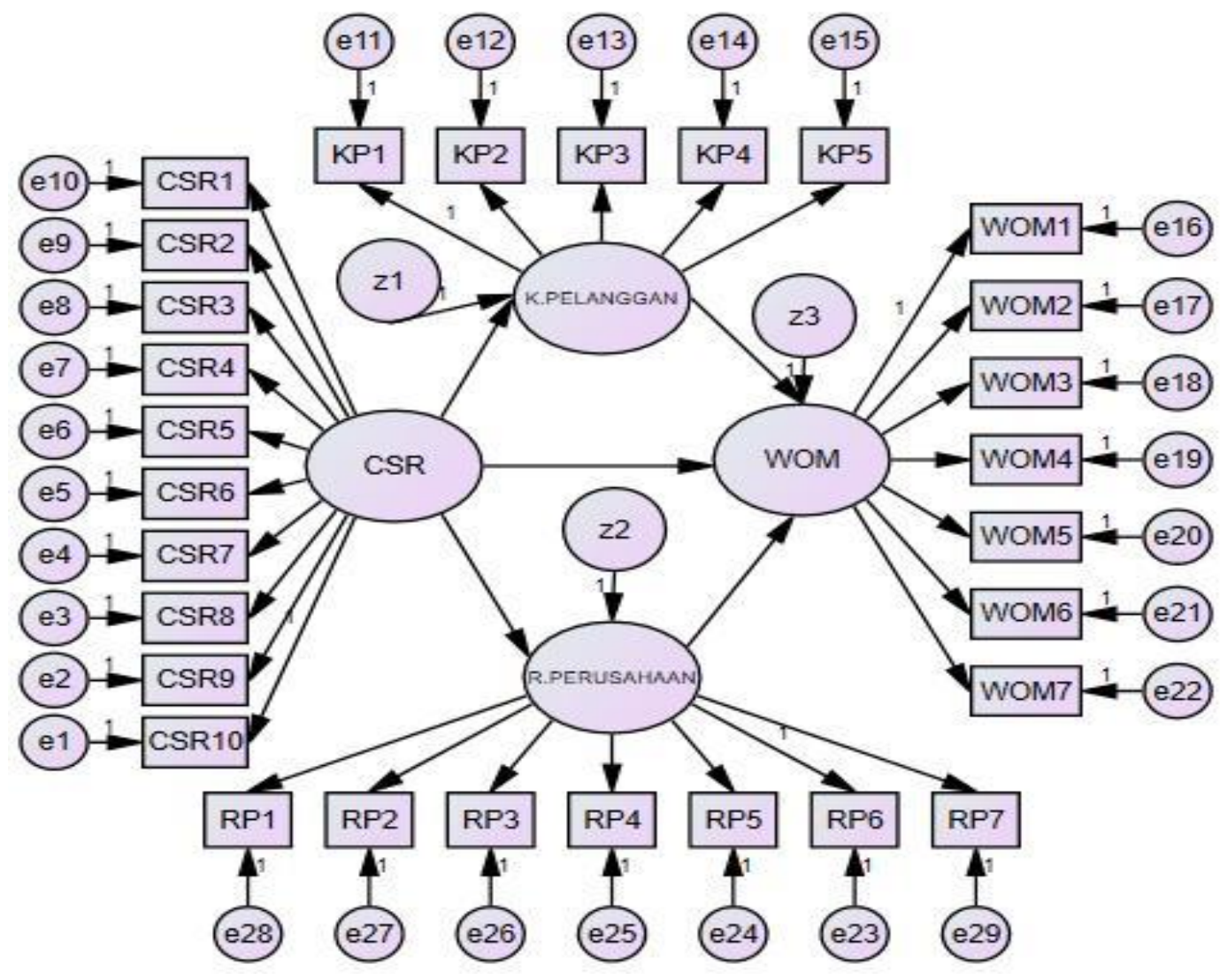

Figure 2: Structural Equation Modeling portraying four latent variables

\section{Normality, Outliers, Multicollinearity Test}

Normality test is used to determine whether data set is well-modeled by a normal distribution and to compute how likely it is for a random variable underlying the data set to be normally distributed, the result shows that all of the data were not normally distributed with some of construct's kurtosis critical ratio or skewness are more or less than $\pm 2,58$. Furthermore to test the normality in this research was using the bootstrap procedure with bootstrap sample $=15$, showed the 
Jurnal Manajemen Bisnis, Vol 9. No 2, September 2018, E-ISSN:2622-6308 P-ISSN:2086-8200

Website: http://journal.umy.ac.id/index.php/mb

DOI:10.18196/mb.9263

score of bollen-stine bootstrap $p=0,063 \geq 0,05$ and it means that the real data are not significantly different with bootstrap data and it could be analyzed.

Outliers is an observation point or data that is distant from other observations, the result shows that there is no data over the mahalanobis d-squared 46,797 . The determinant of sample covariance matrix is also shows that there is no multicollinearity in this research.

\section{Goodness of Fit Index}

The goodness of fit index displayed in Table 2 shows that two from nine indicators are good, fit and accepted.

Table 2. Goodness of Fit Index

\begin{tabular}{llll}
\hline Goodness of Fit Indeks & Cut of Value & Model Result & \\
\hline$X^{2}-$ Chi Square & $\leq 412,67$ & 744,601 & Not Fit \\
Probability & $\geq 0,050$ & 0,000 & Not Fit \\
CMN/DF & $\geq 1 \& \leq 3$ & 2,002 & Good Fit \\
GFI & $\geq 0,900$ & 0,725 & Not Fit \\
RMSEA & $\leq 0,080$ & 0,088 & Marginal Fit \\
AGFI & $\geq 0,900$ & 0,679 & Not Fit \\
TLI & $\geq 0,900$ & 0,875 & Not Fit \\
CFI & $\geq 0,900$ & 0,886 & Not Fit \\
RMR & $\leq 0,05$ & 0,037 & Good Fit \\
\hline
\end{tabular}

According to the parsimony principle, if there were one or two criteria have fit in the whole model it could be stated that whole model is fit [24]. Then the structural equation model testing could be performed.

\section{Regression Weight Test}

The regression weights displayed in Table 3 below shows that the direct effect of variables. 
Jurnal Manajemen Bisnis, Vol 9. No 2, September 2018, E-ISSN:2622-6308 P-ISSN:2086-8200

Website: http://journal.umy.ac.id/index.php/mb

DOI:10.18196/mb.9260

\begin{tabular}{lccc}
\hline \multicolumn{1}{c}{ Hypothesis } & C.R & P & \\
\hline CSR $\rightarrow$ Trust & 8,381 & 0,000 & Significant \\
CSR $\rightarrow$ Corporate Reputation & 9,129 & 0,000 & Significant \\
CSR $\rightarrow$ Word of Mouth & 0,096 & 0,924 & Not Significant \\
CSR $\rightarrow$ Word of Mouth & 0,0858 & 0,391 & Not Significant \\
CSR $\rightarrow$ Word of Mouth & 3,468 & 0,000 & Significant \\
\hline
\end{tabular}

\section{CSR to Trust}

The results of hypothesis test 1 show there was significant influence between CSR and trust. The results of this research can be examined more deeply on indicators that used. This research proves that the commitment of the Hero Supermarket to always keep safety as one form of corporate social responsibility will meet the expectations of its customers.

The consistency of Hero Supermarket in delivering a high-quality services makes customers believe that Hero Supermarket was able to compete with the other supermarkets. These results support the research of [5] [12] which states that corporate social responsibility has a positive and significant effect on trust.

\section{CSR to Corporate Reputation}

The results of hypothesis test 2 show there was a significant effect of CSR on corporate reputation. The company has a goal to enhance the image or reputation of the company in order to ensure the sustainability of its business [25]. Building a good reputation in the community certainly is not an easy thing. Hero Supermarket actively does corporate social responsibility as one form of awareness of the community. These concern action indirectly recorded in the customer minds and creates a good reputation. These results support the research from [2] [10] [13][14] [15] [16] [17] [18] [19] that stated that corporate social responsibility has a positive and significant effect on corporate reputation.

\section{CSR to Word of Mouth}


The results of hypothesis test 3 show there was no significant effect of CSR on word of mouth. Hypothesis 3 was declared not supported which could be caused by the respondents in this study which is mostly students who are between the ages of 17-25 years. Costumer in the aged 17-25 years tend to be experiencer consumers. Experienced consumer is young, enthusiastic and impulsive [22]. This category of consumer has quick enthusiasm towards new product but also quickly to changes [22]. In this research, the whole respondents know and assess good corporate social responsibility carried out by the Hero Supermarkets but are not directly influential on word of mouth. These result is supported the whith research from [16] that stated that corporate social responsibility does not directly effect the word of mouth.

\section{Trust to Word of Mouth}

The results of hypothesis test 4 show there was not significant effect of trust on word of mouth. On five steps of purchase decision model according to [1] explained in decision to buy, customers will pass through several stages, first is introduction of the issue, information retrieval, evaluation of alternatives, purchasing decisions, and post purchase stage. Customer trust occurs at the stage of purchasing decisions after evaluating other alternatives, customers ultimately pick and believe that Hero Supermarket was able to meet his needs. Customers would evaluate the product after purchasing and customers will tend to do word of mouth when satisfied and not if they are changing to other products.

\section{Corporate Reputation to Word of Mouth}

The results of hypothesis test 5 show there was significant effect of corporate reputation on word of mouth. With a good reputation that the products and services provided by the Hero Supermarket became a driving factor for its customers to tell about the quality of the good services of Hero Supermarket and recommend also invite others to shop at Hero Supermarket. Hero Supermarket that always maintains good relations with its customers make 
Jurnal Manajemen Bisnis, Vol 9. No 2, September 2018, E-ISSN:2622-6308 P-ISSN:2086-8200

Website: http://journal.umy.ac.id/index.php/mb

DOI:10.18196/mb.9260

customers want to tell about the positive things that are done by Hero Supermarket. The reputation Hero Supermarket was considered innovative to make customers feel proud to tell that hero as a place to shop. This result supports the research from [2] which concluded that the corporate reputation has a positive and significant effect on word of mouth.

\section{Intervening Test}

Table 4 and 5 below shows the result of the intervening test result with compare of standardized direct effects and standardized Indirect Effects.

Table 4. Standardized Direct Effects

\begin{tabular}{ccccc}
\hline & CSR & Corp. Rep & Trust & WOM \\
\hline Corp. Rep & 0,905 & 0,000 & 0,000 & 0,000 \\
Trust & 0,897 & 0,000 & 0,000 & 0,000 \\
WOM & $-0,021$ & 0,702 & 0,155 & 0,000 \\
\hline
\end{tabular}

Table 5. Standardized Indirect Effects

\begin{tabular}{ccccc}
\hline & CSR & Corp. Rep & Trust & WOM \\
\hline Corp. Rep & 0,000 & 0,000 & 0,000 & 0,000 \\
Trust & 0,000 & 0,000 & 0,000 & 0,000 \\
WOM & 0,774 & 0,000 & 0,000 & 0,000 \\
\hline
\end{tabular}

According to table 4 and table 5 it could be seen that the indirect effect of corporate social responsibility towards word of mouth is 0.774 . The indirect effect on the table is the total of mediation effect of trust and corporate reputation. Then, it need to do additional calculations to see each amount of the mediation effect that could be seen in Figure 2. 


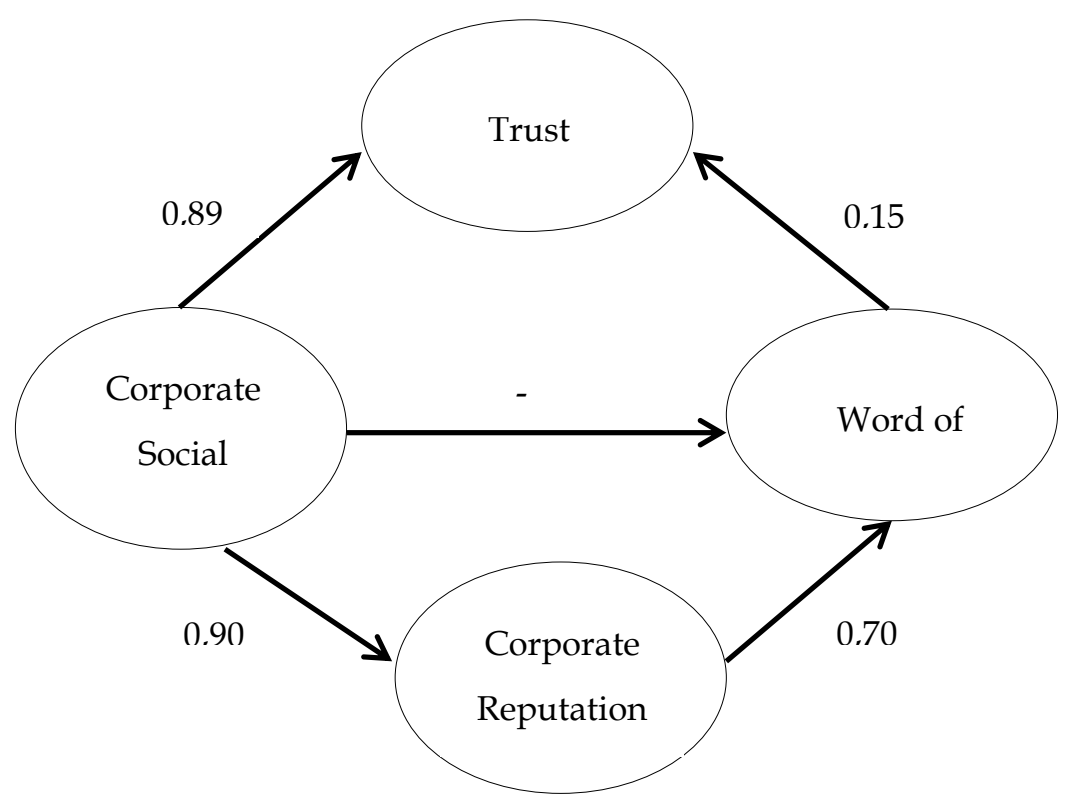

Figure 2. Direct Effect Scores Indirect Effects

CSR->Tr->WOM $\quad=0,897 \times 0,155=0,135$

CSR->Corp.Rep->WOM $=0,905 \times 0,702=0,635$

Total Indirect Effect $\quad=0,774$

\section{CSR to Word of Mouth through Trust as Intervening Variable}

Hypothesis 6 stating that consumer trust is able to mediate the effect of corporate social responsibility towards word of mouth is not supported in this study. The results of the 6 hypotheses are unsupported because to it is associated with hypothesis 3 and 4 . Hypothesis testing of three shows that corporate social responsibility has no effect on word of mouth and results of hypothesis testing 4 shows that consumer trust has no effect on word of mouth. Thus, it indirectly shows that consumer trust could not perform his role as intervening variables because there is no effect between corporate social responsibility on word of mouth and customer trust has no effect on Word of mouth. 
Jurnal Manajemen Bisnis, Vol 9. No 2, September 2018, E-ISSN:2622-6308 P-ISSN:2086-8200

Website: http://journal.umy.ac.id/index.php/mb

DOI:10.18196/mb.9260

CSR to Word of Mouth through Corporate Reputation as Intervening Variable

The results of hypothesis test 7 show that indirect effects are higher than the direct effects, which means that corporate reputation is a good intervening variable in the effect of CSR on Word of mouth. Corporate social responsibility carried out by the Hero Supermarket cannot directly affect its customers to communicate by word of mouth but from hypothesis testing 7, it can be inferred that the social responsibility performed by Hero Supermarkets will affect positively the reputation of the company ahead of time, which the reputation that will improve word of mouth. This result supports the research from [2] that stated that corporate reputation could mediate the effect of corporate social responsibility on word of mouth.

\section{CONCLUSION}

Corporate social responsibility could be an effective marketing strategy to increase the consumer trust and corporate reputation, even though corporate social responsibility could not directly effect word of mouth of the consumer to talk and recommend Hero Supermarket to others, but corporate social responsibility will increase their corporate reputation that will positively affect the word of mouth.

\section{LIMITATION}

Limitation of this study are the respondents of the research which are limited to Hero Supermarket-Yogyakarta although there is more than a hundred store of Hero Supermarket in Indonesia, and also Hero Supermarket is only one brand of the retail industry and it makes the result of this study could not be generalized into industrial scale. The type of this research is cross-sectional research that is only investigated one time and could not show if there are some changes after the research.

\section{RECOMENDATIONS}

Hero Supermarket could use corporate social responsibility to increase consumer trust and corporate reputation which furthermore will also give a significant effect on promotion 
Jurnal Manajemen Bisnis, Vol 9. No 2, September 2018, E-ISSN:2622-6308 P-ISSN:2086-8200

Website: http://journal.umy.ac.id/index.php/mb

DOI:10.18196/mb.9263

strategy with word of mouth of the consumer. Also for future research that investigates the same topic may use another object to show the trend of the result and could plan for longitudinal research to explain more about the changes that could arise during the time.

\section{REFERENCE}

Askeroglu, E. D., \& Bahar, Z., 2014, Contribution of Foundation to Reputation in Corporate Social Responsibility Application: Vodafone Turkey Foundation Review, International Journal of Economic Practices and Theories, 718-725.

Axjonow et al., 2016, The Impact of Corporate Social Responsibility Disclosure on Corporate Reputation: A Non-Professional Stakeholder Perspective, Jurnal Business Ethics, 122.

Bayoud et al., 2012, Corporate Social Responsibility Disclosure and Corporate Reputation in Developing Countries: The Case of Libya, Journal of Business and Policy Research, 131-160.

Bertens, K., 2013, Pengantar Etika Bisnis. Yogyakarta: Kanisius.

Gatti et al., 2012, The Effect of Corporate Reputation, Perceived CSR and Perceived Quality on Intention to Buy: Implication for Brand Management, Journal of Brand Management, 65-76.

Gazzola, P., 2014, Corporate Social Responsibility and Companie's Reputation, Network Intelligence Studies, 74-84.

Ghozali, I., 2012, “Aplikasi Analisis Multivariete dengan Program SPSS”, Badan Penerbitan Universitas Diponegoro, Semarang.

Hair, J. F., Black, W. C., Babin, B. J., Anderson, R. E., \& Tatham, R. L. (2006). Multivariate Data Analysis (6 ed.): Prentice Hall.

Hong, S. Y., \& Rim, H., 2010. The Influence of Customer Use of Corporate Website: Corporate Responsibility, trust, and Word of Mouth Communication, Public Relation Review, 389-391.

Indriani, A. A., \& Nurcaya, I. N., 2015, Pengaruh Kualitas Pelayanan terhadap Word of Mouth yang Dimediasi oleh Kepercayaan Pelanggan pada PT. Auto Bagus Rent A Car Denpasar, E-Jurnal Manajemen Unud, 1301-1321.

Khan et al., 2013, Corporate Social Responsiblity and Corporate Reputation: A Case of Cement Industry in Pakistan, Interdiciplinary Journal of Contemporary Research in Business, 843-857.

Kotler, P., \& Keller, K. L., 2007, Unleashing the Power of Word of Mouth: Creating Brand Advocacy to Drive Growth, the Journal of Advertising Research. ARF.

Kotler, P., \& Keller, K. L., 2016, Marketing Management. London: Pearson.

Margaretha, F., \& Isnaini, R., 2014, Board Diversity and Gender Composition on Corporate Social Responsibility and Firm Reputation in Indonesia, Jurnal Manajemen dan Kewirausahaan, 1-8.

Muhadjir \& Qurani, G. F., 2011, Pengaruh Penerapan Corporate Social Responsibility terhadap Persepsi Nasabah Bank dan Dampaknya terhadap Corporate Image, Journal The Winners, 180-195. 
Jurnal Manajemen Bisnis, Vol 9. No 2, September 2018, E-ISSN:2622-6308 P-ISSN:2086-8200

Website: http://journal.umy.ac.id/index.php/mb

DOI:10.18196/mb.9260

Muttaqin, M. R., \& Utama, A., 2016, Pengaruh Tanggung Jawab Sosial Terhadap Word of Mouth yang Dimediasi oleh Kepercayaan Pelanggan (Studi Kasus pada Carrefour Amplaz Yogyakarta), Jurnal Manajemen Bisnis, 493-503.

Pasar dan Corporate Social Responsibility dengan Kinerja Bisnis, Jurnal Buletin Studi Ekonomi, 164-174.

Peter, J. P., \& Olson, J. C., 2014, Perilaku Konsumen \& Strategi Pemasaran. Jakarta: Salemba Empat.

Putra, D. K., \& Saputri, N. D., 2015, Komunikasi Cyber CSR: Analisis Isi pada Official Website PT Bank Pembangunan Daerah Jawa Barat dan Banten, Channel, 17-39.

Rihayana, G., 2014, Peran Mediasi Reputasi Perusahaan terhadap Hubungan Orientasi

Semuel, H., \& Chandra, S. S., 2014, Analisa Pengaruh Penerapan CSR terhadap Price Fairness, Trust and Purchase Intention Produk Kosmetik Merek Oriflame di Surabaya, Jurnal Spread, 21-32.

Solimun, 2004, Pemodelan Statistika Structural Equation Modeling Aplikasi AMOS, Fakultas MIPA dan Program Pascasarjana Universitas Brawijaya, Malang.

Sridhar, M., \& Ganesan, P., 2016, The Effect of Corporate Social Responsibility on Customer Performance and Behavioral Intention - Testing the Mediating Role of Reputation of A Private University, Great Lakes Herald, 1-37.

Syah, T. Y., 2013, Perbedaan Pengaruh Citra Merek dan Reputasi Perusahaan terhadap Kualitas Produk, Nilai Pelanggan dan Loyalitas Pelanggan di Pasar Bisnis, Jurnal Ekonomi, 4(2), 209-226.

Tong, C., \& Wong, A., 2014, The Influences of Corporate Social Responsibility to Customer Repurchases Intentions, Customer Word of Mouth Intentions and Customer Perceived Food Quality of Fast-Food Restaurants in Hong Kong and the Mediating Effects of Corporate Reputation, British Journal of Economics, Management \& Trade, $1655-1678$.

Warin et al., 2013, Corporate Reputation and Social Media: A Game Theory Approach, Cirano, 1-19. 